August 25, 2003

\title{
Efficiency and equality in the labour market
}

\author{
Jonas Agell $^{*}$
}

\begin{abstract}
This paper discusses the costs and benefits of welfare state intervention in the labour market, and argues that many forms of intervention can be justified for efficiency reasons. The paper reviews recent evidence on income inequality and income mobility, and it discusses labour market reforms that may improve efficiency without violating European voters' preference for equality.

JEL classification: H30, J30, J50,
\end{abstract}

Key words: welfare state, collective bargaining, inequality, labour market reform

\footnotetext{
* The paper was prepared for the Munich Economic Summit, May 2-3 2003. I am grateful for helpful comments from Susanne Ackum Agell, Anders Björklund, Yngve Lindh and Anna Nilsson.

Contact information: Jonas Agell, Department of Economics, Stockholm University, SE-106 91 Stockholm, SWEDEN.

email: JA@ne.su.se

phone: +468163851
} 
Unemployment in the United States stood at 6.8 percent in 1991, and dropped to a post-war low of 4.0 percent in 2000. ${ }^{1}$ At the same time leading European economies struggled to keep their unemployment rates below 10 percent. The average unemployment rate in the European Union was 8.1 percent in 1991, increased to 10.6 percent in 1996 , and fell back to 8.1 percent in 2000. In the United States only 6 percent of total unemployment in the year 2000 consisted of people who had been unemployed for at least a year. In Germany, Belgium and Italy longterm unemployment was more than 50 percent of the total. Between 1991-2000 the US economy created 17.5 million additional jobs (an increase by 15 percent), while the European Union only created 12.4 million additional jobs (an increase by 8 percent).

The marked contrast between U.S. and European labour market performance is often attributed to the lack of flexibility in European labour markets. Today many economists agree that generous social insurance, employment protection, minimum wages and centralized wage determination create much wastage, in the form of unemployment, and compressed wage structures that distort people's incentives to look for new jobs and invest in human capital. As a corollary, it is often argued that far-reaching labour market deregulation is the only way to create a job miracle in European labour markets.

In this paper I will agree that some European institutions create inefficiencies, with small or no compensating gains in terms of equity/income security. I also believe that the U.S. welfare reforms of the 1990s offer useful lessons for European policy-makers. But my main message is that Europeans should not throw out the baby with the bathwater. There is in fact both a cost and a benefit side to labour market institutions. Although it seems likely that certain institutions create unemployment, others may in fact serve quite useful purposes. Reforms failing to distinguish between good and bad rigidities will do more harm than good.

\footnotetext{
${ }^{1}$ The facts in this paragraph are taken from the OECD Employment Outlook (2002).
} 
A basic objection to the view that adverse European institutions is the only factor behind the US-European divergence in labour market performance is that most European countries had in fact lower, or much lower, unemployment rates than the United States in the 1960s and early 1970s. As noted by Blanchard and Wolfers (2000) and Bertola, Blau and Kahn (2001) most of today's institutions were in fact the same already in the early 1960s. This makes it unlikely that adverse institutions can be the only factor behind the more recent developments. It appears likely that macroeconomic events, and their interactions with institutions, play important roles as well; see e.g. Blanchard and Wolfers (2000) and Bertola, Blau and Kahn (2001). Moreover, as stressed by Nickell (1997) there is large diversity within Europe. Though persistent unemployment is a serious issue in Germany, Italy and Spain, several of the smaller European countries have for long had unemployment rates on par with, or even below, the United States. This includes Denmark, Norway, the Netherlands and Austria, countries with extensive welfare states, encompassing institutions of collective bargaining, and - with the exception of Denmark - strict job protection. At the same time, it is noteworthy that the United Kingdom, which deregulated its labour markets in the 1980s, did not fare significantly better than the average European economy during the $1990 \mathrm{~s}^{2}$

\section{Labour market institutions in second-best environments}

Every student of economics knows that an efficient resource allocation will emerge if all agents in the labour market are price takers, and if there is a complete set of markets. The resulting allocation need not be an equitable one, but it will maximize the size of the pie (i.e. the sum of all producer and consumer surpluses). Viewed against the yardstick of such an idealized competitive environment, European-style labour market institutions are bound to

\footnotetext{
${ }^{2}$ In the 1996-2000 period the (OECD-standardized) average unemployment rates in the countries discussed in this paragraph were as follows: Austria $4.2 \%$, Denmark $5.1 \%$, Germany $8.9 \%$, Italy $11.3 \%$, Netherlands $4.1 \%$, Norway $3.9 \%$, Spain $18.2 \%$, the United Kingdom 6.5\% and the United States 4.6\%. (Source: OECD Employment Outlook.)
} 
create efficiency losses. Unions and minimum wages that push up the wages of low-skilled workers will reduce output and create unskilled unemployment. Taxation and generous social insurance will provide workers with an incentive to replace work in the high-productive market sector with less productive leisure and activities in the underground economy.

Viewed against the yardstick of an economy with pre-existing market failures matters need not be so bleak. It is a standard result in welfare economics that because of externalities, public goods, increasing returns and asymmetric information there is - at least in theory - a case for government intervention. These market failures may also explain why labour market institutions that e.g. compress wages can improve efficiency. A classic example is that of the employment and welfare effects of minimum wages. When the minimum wage is introduced in a perfectly competitive economy it is bound to reduce efficiency. But when it is introduced in a labour market where the firm has all the market power the firm is provided with the incentive to increase employment towards the first-best level.

A recent literature has explored the implications of labour market models that incorporate the standard market failures of welfare economics. A main theme of these papers is that many of the labour market institutions that have quite detrimental effects in perfectly competitive environments may have a beneficial impact in models with pre-existing market failures. ${ }^{3}$ This is not the time to review this literature, which covers a lot of ground. Instead, I will briefly discuss under what conditions institutional wage compression - a hallmark of European labour markets - can in fact be motivated for reasons of economic efficiency.

Missing insurance markets. It has been said that "Uncertainty and expectations are the joys of life". But for risk-averse individuals uncertainty should be a cause of concern. For most individuals human capital is by far the most important asset. Yet, the private insurance market will not accommodate people's demand for protection against a variety of risks that

\footnotetext{
${ }^{3}$ See e.g. Agell and Lommerud $(1992,1997)$ on institutional wage compression, Atkinson (1999) and Acemoglu and Shimer (1999) on unemployment benefits, and Pissarides (2001) on employment protection.
} 
originate in the labour market. In particular, for reasons of asymmetric information, and because of the problems of enforcing long-run insurance contracts involving human capital, the insurance industry will not provide protection against long-term career risk. ${ }^{5}$

It is a standard result that missing insurance markets suggests an important role for government redistribution policy. By reducing the variance of disposable income, a system of redistributive taxes and transfers may improve welfare by providing an insurance effect in addition to the conventional incentive and equity effects. Several authors have even suggested that missing insurance markets explains why the modern tax-financed welfare state fulfils an important efficiency purpose, which goes beyond conventional justifications in terms of fairness and equality; cf. Atkinson (1991, 1999), Barr (1998) and Sandmo (1991, 1998). Though the welfare state imposes tax wedges that are detrimental to economic efficiency, voters are willing to pay this cost because they receive compensating insurance benefits.

But income redistribution via the welfare state is not the only way of purchasing insurance against the uncertainties of the future. Insurance can also be provided through labour market institutions (egalitarian unions, minimum wage legislation and unemployment insurance) that narrow the earnings distribution. As discussed by Agell and Lommerud (1992), under general assumptions the insurance benefits from a "small" compression of the wage distribution will outweigh any efficiency losses imposed on the economy. It is important to note that in this analysis egalitarian unions do create unemployment among their unskilled members, but in spite of this the expected utility of the average worker will be higher than in a laissez-faire economy with no unemployment. In the model of Agell and Lommerud unemployment is simply the cost associated with a second-best insurance contract.

As pointed out by Sinn (1995) the social insurance approach to the institutions of the welfare state has an intriguing implication. It is a common belief that the high taxes of the

\footnotetext{
${ }^{4}$ Congreve, Love for love, as quoted by Hicks (1946, p. 189).

${ }^{5}$ For a discussion stressing the inability of insurance markets to handle career risk, see Sinn (1996).
} 
welfare state are necessarily bad for investments and entrepreneurship. But Sinn shows that properly designed welfare institutions may in fact encourage people to undertake risky activities. Sinn extends the model of social insurance via the tax system to the case when individuals can invest in risky activities, and he shows that the insurance provided via redistributive taxes and benefits may lead to increased investments in risky activities. In the words of Sinn "...under the protection of the welfare state more can be dared".

The idea that properly designed social insurance may encourage risk taking and productive investments is in fact an old one. In defending social insurance against the supporters of laissez faire, Cassel (1900) wrote approvingly of a social policy aimed at protecting the working class. He argued that social policy was a powerful instrument to promote economic progress, and to induce people to accept change. He even went so far so as to state that "...the main point in defence of this policy must rest in the acknowledgement that the productivity of labour increases in parallel with the social position of the working class. The insight about this relationship is the most optimistic, but at the same time one of the most well-established, results of modern economic research." (Cassel, 1900, p. 387-388).

Wage compression and incentives for human capital formation. A very common argument in the debate about European labour markets is that a compressed wage structure reduces people's incentives to acquire human capital. As governments and egalitarian unions attempt to raise the pay of those at the low-end of the skill distribution they also reduce the return on investments in education and training. As a consequence there will be too little investment in human capital.

Recent work suggests that this argument needs to be qualified. Institutional compression of the wage structure from below may in fact initiate push-effects, which counter the traditional disincentive effect from wage compression. The schooling decision depends on the return to schooling. But what is forgotten in the traditional analysis is that it will also 
depend on the skill requirements of firms. When the relative wage of unskilled workers increases firms hire fewer workers with little schooling and experience. To avoid unemployment, and to get access to the primary job market, young people will then simply have to acquire more schooling. ${ }^{6}$ As shown by Cahuc and Michel (1996), Agell and Lommerud (1997) and Ravn and Sørensen (1997) it is not difficult to write down models in which a binding minimum wage for unskilled workers will lead to a more highly educated workforce. It is important to note that it is the very fact that the minimum wage creates unemployment among unskilled workers (i.e. the standard objection to minimum wages) that leads to an upgrading of the human capital stock.

Kahn (2000) reports some empirical support for this mechanism. Using micro-data for 15 OECD countries Kahn finds that greater union coverage/union membership leads to higher relative wages and lower employment for young men. The effects for young women are similar but weaker. Interestingly, Kahn reports that greater union coverage/union membership also leads to a greater propensity to attend school for both genders. These correlations are exactly what we would expect from the theoretical arguments of the preceding paragraph.

A related analysis of the link between wage compression and human capital formation is provided by Acemoglu and Pischke (1999), who concentrate on on-the-job training. In their model various frictions in the labour market are assumed to lock a firm and its employees into a bilateral monopoly situation. In the local wage bargain the firm will therefore be able to appropriate part of the returns to workers' investments in general training. Because workers anticipate this, they may end up not investing in general training. Acemoglu and Pischke (1999) show that the firm may want to compensate for this by investing resources in the general skills of their employees. They also show that such firm-sponsored investments should be more common when the wage structure is compressed against skilled workers.

\footnotetext{
${ }^{6}$ In effect, low skilled unemployment lowers the opportunity cost of going to school. It is important to note that for this effect to occur it must be unpleasant to be unemployed. With very generous unemployment
} 
Summing up, it is often taken for granted that unions, and the welfare state, might be good for reasons of equity, but that these institutions are harmful to economic efficiency. Here, we have seen that it is in fact possible to find efficiency-based justifications for unions and the welfare state. Obviously, this does not imply that today's labour market institutions in Europe are without faults. As I will discuss below, many institutions appear to be designed in ways that impose deadweight burdens that are unnecessarily large. But the research reviewed in this section suggests that supporters of a big-bang approach to European labour market reform have an unbalanced case. The intellectual support for the idea that only far-reaching labour market deregulation can restore European prosperity can be traced to investigations that assume that the appropriate benchmark when discussing European institutions is a perfectly competitive labour market. ${ }^{7}$ Though such an approach might be useful in mapping out the costs of labour market institutions, it has nothing to say about the potential benefits.

\section{Inequality, poverty and income mobility}

The traditional motivation for many of the institutional arrangements in European labour markets is that they promote fairness and egalitarian outcomes. More recently, however, a growing number of critics have argued that also those in favour of equity and income inequality have reason to reconsider these institutions. It is argued that the welfare states of Northern Europe create inequality/poverty by protecting the interests of employed insiders at the expense unemployed outsiders. It is also argued that welfare states tend to be static societies with little income mobility, and that large segments of the populations of these countries are locked into long-term dependence on social assistance. By contrast, it is often argued that the flexible labour markets of the United States provide poor people with significantly greater opportunity for upward income mobility. 
This section briefly reviews some basic facts and research on income inequality, poverty and income mobility in different countries. Most of my discussion focuses on a comparison between the United States and the United Kingdom (i.e. countries with flexible labour markets) and European countries with rigid labour markets. I will rely heavily on evidence from the Luxembourg Income Study (LIS). ${ }^{8}$ LIS comprises household survey data for 26 industrialized countries. Though cross-country comparisons of income inequality are subject to a number of methodological problems, LIS is most certainly the most reliable source of such information. First, over the years much has been invested in achieving comparability across countries. Second, it is well known that the inequality of earnings is much smaller in many European countries than it is in the United States. But since statistics on earnings inequality exclude the long-term unemployed, which is a sizeable group in some European countries, such comparisons will overstate equality in Europe; see Heckman (2001). Since the LIS project allows for a systematic comparison of the distribution of disposable income in random household samples, this bias is avoided.

Table 1 presents some basic statistics on income inequality and poverty. For each country the figures refer to the most recently available year, which typically is a year in the mid to late 1990s. ${ }^{9}$ The first column shows the ratio of the disposable incomes of the persons at the bottom and top deciles. This "decile ratio" is easy to interpret, and it allows for a direct comparison of the distance between people at the top and bottom of the income distribution. As noted by Gottschalk and Smeeding (1997), Björklund (1998) and Smeeding (2002) countries tend to cluster into different geographical groups. Income differentials are the smallest in Scandinavia (Sweden, Finland, Denmark and Norway) and parts of Northern Europe (Luxembourg, Netherlands, Germany and Belgium), with decile ratios below or around 3. Parts of Continental Europe come next; in France, Switzerland and Austria decile

\footnotetext{
${ }^{8}$ For presentations of the LIS project, see Atkinson, Rainwater and Smeeding (1995), and Smeeding (2002).
} 
ratios range from 3.54 to 3.73. Income inequality is the highest in Southern Europe (Spain and Italy) and the English speaking countries of Canada, Australia, Ireland, the United Kingdom and the United States, where the decile ratios typically exceed 4. The biggest distance between rich and poor is in the United States, where the ratio is 5.57. This is about twice the ratio that can be found in the quartet of Sweden, Finland, Luxembourg and Denmark.

The indicators shown in the following columns convey a similar picture. The Gini coefficient is a commonly used global inequality measure, which takes a value of zero in a country where everyone has the same disposable income, and a value of unity in a country where a single individual earns all income. Column 2 shows that the ranking of countries remains almost the same as in column 1. Scandinavia and Northern Europe have Gini coefficients falling between .22 and .26; the United Kingdom and the United States have Gini coefficients of .344 and .372 . By the standard of Gini comparisons this is a large discrepancy. A common measure of inequality at the lower end of the income distribution is the relative poverty rate, shown in column 3 . This column shows the percentage of the population with an income below 50 percent of the median income (poverty researcher sometimes view this as an indicator of the extent of social exclusion in society). Relative poverty is the lowest in Scandinavia and Northern Europe, and the highest in Southern Europe and the Englishspeaking countries. The United States has the highest relative poverty rate, 17 percent.

It could be argued that poverty among healthy adults is a lesser problem; a poor individual could simply be someone with a preference for consuming leisure rather than consumption goods. However, this argument does not apply to children. Column 4 shows that the imbalances in relative poverty rates across countries grow larger when we confine attention to the distribution of disposable income among children. Some of the Scandinavian welfare states spend large sums to support families with children, and the relative poverty

\footnotetext{
${ }^{9}$ These results are directly available at the LIS home page: www.lisproject.org/keyfigures. Smeeding (2002) discusses issues of measurement and comparability.
} 
rates among children in Finland and Sweden are below 3 percent. The relative poverty rates among children in the United Kingdom and the United States are 15.4 and 21.9 percent.

Finally, it is of interest to measure poverty using an absolute rather than relative measurement rod. Using the official poverty rate of the United States as the relevant (purchasing power adjusted) standard in all countries, Bradbury and Jäntti (2002) compute the share of children in each country that can be classified as living in absolute poverty. Their results are shown in column 5. Though GDP per capita is some 30 percent larger in the United States than in Scandinavia and Northern Europe, the United States has the highest incidence of absolute child poverty. While 13.9 percent of children in the United States live in poverty, the corresponding figures are 1.2 percent in Luxembourg, 3.0 percent in Norway, 5.1 percent in Denmark, 5.3 percent in Sweden, and 6.9 percent in Finland. Finally, the incidence of absolute child poverty in the United Kingdom - a country with a GDP per capita on par with Finland and Sweden - is as high as 29.1 percent.

The conclusion from these comparisons seems to be that the institutions of Scandinavia and Northern Europe are - whatever their efficiency costs may be - relatively successful in achieving economic equality. According to the criteria used by distribution analysts and poverty researchers the institutions of the United States and the United Kingdom create more inequality, and more poverty, among children and among the population at large. It should be noted that the poor showing of the United States in Table 1 occurs in spite of a decade with rapid employment growth in the American labour market. Thus, a job miracle is no cure-all for the problems of inequality and poverty.

An objection to these comparisons is that they rely on data for a single year. The fact that the welfare states of Scandinavia and Northern Europe seem to be doing rather well in equalizing incomes could simply be an artefact from measuring incomes over too short periods. In societies with much upward income mobility, which is often thought to be the case 
in the United States, the inequality of annual income will exaggerate the inequality of long run - or permanent - income. Because of high income mobility, the inequality of permanent income in the United States might in fact be low, in spite of high inequality of annual income.

A recent analysis of this issue is provided by Aaberge et al. (2002). This paper compares income inequality and income mobility in the Scandinavian countries and the United States during the period 1980-90. The results suggest that inequality of annual income is far greater in the United States, but it is also shown that this continues to be the case when the accounting period is extended from one to eleven years. Other results are that there is no unequivocal way of ranking different countries in terms of income mobility, and that the mobility differences between countries appear to be small. In a related analysis Burkhauser and Poupore (1997) study income mobility in Germany and the United States over the fiveyear period 1983-1988. They find that Germany and the United States have remarkably similar mobility patterns. Duncan et al. (1993) compare transitions in and out of poverty in eight countries, including e.g. the United States, Germany (not including former East Germany), France, the Netherlands, and Sweden. They conclude that the “...extent of upward mobility appears to be just as great among the poor in Europe as among US poor" (Duncan et al. (1993, p. 229)).

A more long-term perspective on income mobility is provided by the literature on intergenerational income mobility. Here, the issue at stake is the correlation between the earnings of fathers and sons. In a society where this correlation is close to zero there will be a high degree of intergenerational mobility, in the sense that the earnings of the father will not condition the earnings of his son. The recent review of Solon (2002) suggests - very much contrary to the popular belief - that there is less intergenerational mobility in the United States and the United Kingdom than in other countries. While studies for these two countries 
report correlations in excess of .4, studies for Sweden, Finland and Germany report correlations in a range from .11 to .34 .

In sum, there is no evidence that high income mobility in the United States - over lifecycles and across generations - compensates for the higher or much higher rates of income inequality and poverty observed in annual income data. The welfare states of Scandinavia and Northern Europe have both significantly less cross-sectional inequality and higher intergenerational mobility than the United States. ${ }^{10}$

What institutional characteristics generate equality? Since the welfare states of Northern Europe have it all, answering this question in a very precise manner might not be so easy. These countries have generous social transfer systems, but they also have labour market institutions that compress the distribution of earnings from below, education systems that produce a more compressed distribution of human capital, and progressive tax systems. Trying to decompose the overall equalising impact of this institutional sum into its component parts raises difficult issues in general equilibrium modelling. Nevertheless, Smeeding (2002) concludes that explanations for cross-country differences in inequality appear to differ according to which end of the income distribution one is studying. Smeeding shows that there appears to be a negative relationship between cross-country poverty rates and wages at the bottom of the wage distribution. He also shows that there appears to be a negative relationship between poverty rates and a country's social expenditure level as a percentage of GDP.

I show a similar scatter diagram in Figure 1, which plots the incidence of child poverty against total social spending (after deducting cash payments to the elderly) in 18 OECDcountries. ${ }^{11}$ The OLS regression line is downward sloping, with a $t$-value of 4.98. I also checked whether there was a statistically significant correlation between child poverty and the

\footnotetext{
${ }^{10}$ Björklund and Jäntti (1997) go so far so as to conjecture that cross-sectional equality of outcomes within generations might be conducive to intergenerational mobility in society.
} 
measure of minimum wages used by e.g. Nickell and Layard (1999). This was not the case, however. Though the minimum wage variable did show up with a negative sign in an OLS regression, the $t$-value was only .81 .

\section{Is the flexible U.S. labour market an appropriate model for Europe?}

The view that major labour market deregulation and scaling down of the welfare state is the only way forward rests on two key assumptions. First, it assumes that a deregulated labour market is the best way to serve economic efficiency. Second, it assumes that far-reaching labour market deregulation and major reform of the welfare state would be of little consequence for equality and the fight against poverty. In my view both assumptions are dubious, or wrong. Sound principles of welfare economics, and available cross-country evidence on income inequality and income mobility, suggest that some rigidities are good for economic efficiency, and that the welfare state has been successful in reducing inequality.

As noted by Krueger (2002) all societies must find ways of striking a balance between the beneficial incentive effects of inequality and the harmful welfare-decreasing effects of inequality. This balancing act will depend on the preferences of voters. It will also depend on all the factors in the economic environment that impact on voters' perceptions of the benefits and costs from institutions that provide social insurance and redistribute income between rich and poor. Here, the important observation is that European voters appear to have a strong preference for the welfare state. When Boeri, Börsch-Supan and Tabellini (2001) surveyed citizens in France, Germany, Italy and Spain, they found that sizeable majorities in all countries opposed cuts to social security and welfare spending. A majority of respondents also indicated a high willingness to pay for insurance against labour market risk.

\footnotetext{
${ }^{11}$ The relative child poverty rate is the one shown in Table 1. The data on social spending (after deducting old age cash benefits) as a percentage of GDP apply to 1998, and they are downloadable from the OECD Social
} 


\section{What can be done?}

What labour market reforms may improve economic efficiency without violating European voters' preference for fairness? Answering this question is not so easy. After all, there is not supposed to be a free lunch in economics. And since Europe is so diverse optimal reform packages will differ quite a lot between countries. The labour market problems of Germany are not the same as the problems of Sweden and Italy. Keeping this in mind, I will here stick to the safe haven of general reasoning rather than concrete policy advice.

\section{5a) Schooling}

In striking a balance between efficiency and equality, redistributive taxes and transfers are not the only available policy instruments. In the long-term, a country's schooling and training policies are more decisive factors. ${ }^{12}$ Schooling systems and training programs that are successful in upgrading the skills and human capital at the low end of the ability distribution yield multiple returns. First, there will be private returns to the individuals involved. Second, in countries where voters have an aversion to income dispersion a more compressed productivity distribution has a value of its own. Third, a more compressed productivity distribution will reduce the need to rely on redistributive taxation, which reduces the deadweight loss from taxation (see Dur and Teulings (2002) for a theoretical analysis).

The preceding argument has some bearing upon the recent discussion about whether the European welfare states should try to create a job miracle of their own by forming a lowwage service sector without minimum wages and collective bargaining contracts. The largest efficiency gains from having such a sector should materialise in countries with a dispersed distribution human capital. When a U.S. computer specialist gets some extra time at his office by "outsourcing" household production to a lowly educated immigrant worker there will be a 
large societal gain in the utilisation of the human capital of the former. In European countries, where schools and training programs produce a more compressed distribution of skills (see e.g. Nickell and Bell (1996)), the gain will be much smaller. Based on this logic, I argue that the reason that the unskilled service sector is significantly less important in Northern Europe than in the United States probably hinges at least as much on several decades of past education policy as on unions and collective bargaining.

\section{5b) The trade-off between generosity and punishments}

Atkinson (1999) points out that critics of social insurance and social policy often tend to neglect the importance of institutional detail. The behavioural consequences of a given social spending budget will depend crucially on a wide range of design features. Taking unemployment benefits as an illustration, Atkinson notes that real-world benefit systems are subject to contribution conditions, often prescribe that benefits should have limited duration, and may impose active job search requirements. Moreover, persons who quit voluntarily, are dismissed because of misconduct, or reject job offers, may be disqualified from receiving benefits. Supporters of the big-bang approach rarely acknowledge such fine prints; typically, the issue that is stressed is the adverse consequences of generous benefit levels. Yet, Atkinson presents several examples of how generous benefits can be made incentive-compatible by adding on eligibility and job search requirements, and sanctions for misconduct.

These insights are of considerable importance for many areas of social policy design. Generous compensation levels in social insurance need not be a problem, as long as there are ways of preventing misuse. Spelling out clear eligibility criteria, monitoring compliance and imposing sanctions are crucial aspects of optimal social policy design. It appears, however, that these issues are often treated with undue neglect. Many governments spend large

\footnotetext{
${ }^{12}$ For a discussion of the pros and cons of investments in different forms of training and schooling, see Carneiro and Heckman (2003) and Krueger (2002).
} 
resources to detect and punish tax evaders, and yet do very little to detect and punish people that cheat on social insurance. Recent work by Lalive, van Ours and Zweimuller (2002) shows that addressing this imbalance may produce large beneficial responses. Lalive et al. use Swiss data to explore the effectiveness of benefit sanctions on unemployment duration, and they separate the effect of a warning that a person is not complying with eligibility requirements from the actual enforcement of the punishment. The results indicate that both warning and enforcement have positive effects on the exit rate out of unemployment, and that increasing the monitoring intensity reduces the duration of unemployment.

Finally, it is of interest to note that recent experimental evidence shows that people are willing to invest substantial resources in public goods, as long as they have the possibility to inflict punishment on those who free ride on the co-operation of others, see Fehr and Gächter (2002). Fehr and Gächter show that free riding triggers strong negative emotions, and that cooperation may break down altogether in the absence of punishments. Taken at face value these results appear to have some profound implications for the organization of the welfare state. Majority support for a generous welfare state may require that the government invests significant resources in identifying and punishing those engaging in anti-social behaviour.

\section{5c) Labour supply incentives -- the problematic $U$-curve}

A common characteristic of labour supply incentives in many countries is that workers at the low and high ends of the wage distribution face the highest marginal tax rates. In a diagram plotting the marginal tax rate on the $y$-axis and taxable income on the $\mathrm{x}$-axis the schedule of marginal tax brackets will be shaped like a U. At the low end, the interaction of income taxes and income-dependent transfers (like housing subsidies and social assistance) implies that e.g. unskilled, lone parents will be confronted with very high effective marginal tax rates. When the marginal tax rate exceeds 100 percent there will be a poverty trap, which effectively 
discourages labour force participation. At the high end, skilled workers face higher than normal marginal tax rates, the reason being that real-world tax systems prescribe that the marginal tax rate should be some increasing function of taxable income. Available econometric studies of labour supply indicate that the U-curve of labour supply disincentives may create potentially large excess burdens.

Both practical and theoretical considerations suggest that these problems can be mitigated, without compromising distributional objectives. During the 1990s the United States greatly expanded the use of the so-called earned income tax credit. This scheme is only available to working poor families, and it gives a tax credit directly related to the size of earnings and the number of children. The attractive aspect is that it enhances the incomes of the working poor, and at the same time provides a substantial boost to work incentives. The downside is that for individuals with earned incomes falling in the phase-out range of the tax credit there will be an added disincentive effect. However, recent research suggests that the earned income tax credit has had a positive net impact on the labour supply of lone mothers. ${ }^{13}$

When it comes to the high end of the wage distribution the theory of optimal income taxation, following Mirrlees (1971), offers some guidance. This theory may appear arcane to the non-specialist, but there is one finding of significant policy interest. There is no support at all for the common view that equality is best served by a tax system with increasing marginal tax rates at the top of the wage distribution. Numerical simulations suggest that marginal tax rates should stay fairly constant, or even decrease, as we reach the higher end of the earnings distribution, see e.g. Heady (1993). This result applies even when the government cares a lot about the utility of the poor: rate cuts that increase the labour supply of high-wage individuals provide extra tax revenue that can be redistributed to low-wage individuals.

\footnotetext{
${ }^{13}$ See Meyer and Rosenbaum (2001). Blank (2003) makes the important related point that lone mothers also need help with adequate day care to ease the transition into permanent jobs.
} 


\section{5d) Work and training requirements}

Many empirical studies have documented that paying out generous unemployment benefits or cash assistance for long durations generate long-term unemployment; see e.g. Nickell and Layard (1999). One way of reducing this problem is to introduce explicit work and/or training requirements: after a suitable waiting period, further financial assistance will only be allowed if the person accepts to participate in some work or training programme. While some European countries already adopt such schemes, the United States has seen a large expansion of work programs during the 1990s. A particularly interesting aspect is that the U.S. programs have been extensively evaluated using state-of-the-art randomised evaluations; see Blank (2002, 2003) for overviews. Blank (2003, p. 59) concludes that there is now a “...substantial body of evidence on the effectiveness of welfare-to-work programs in reducing welfare usage and public costs, and increasing labour supply."

Blank (2003) also notes that mandatory work requirements (a negative incentive) probably work best in combination with a positive incentive, of which the earned income tax credit might be a good example. Viewed in isolation welfare-to-work programmes may have a significant effect on labour supply, but no effect at all on overall income or poverty. When combined with something like the earned income tax credit, there will also be a positive income effect that may reduce poverty.

\section{5e) Taming non-coordinated unions}

Cross-country investigations of why unemployment rates differ suggest that co-ordinated unions are more likely to consider the aggregate employment consequences when wage bargains are struck; see e.g. Nickell and Layard (1999). Such co-ordination will occur naturally in countries with highly centralised wage bargaining, like e.g. Austria and the Netherlands, or Sweden in the decades following the Second World War. All-encompassing 
unions operating at the national level may even have an incentive to internalise some of the negative incentive effects from high tax wedges; cf. Summers, Gruber and Vergara (1993).

In many countries unemployment benefits are financed out of general tax money to a very large extent. In Sweden, for example, unemployment insurance has traditionally been run by the unions in the form of a number of certified unemployment insurance funds. While part of the financing stems from union membership fees the government provides large subsidies, financed by general tax money. After a design change in the 1980s the membership fee is in fact independent of the unemployment rate in the area of the specific fund; in effect, the marginal cost of unemployment for a single fund became zero. In an economy with centralised bargaining at the national level marginal subsidies on this scale should be of no consequence, since the employees' federation should see through the government's budget constraint, and recognise that higher subsidies means higher taxes on labour.

In an economy where bargaining rather takes place along sectoral lines, which is the case in many European countries, such generous marginal subsidies imply strong incentives for macroeconomic free-riding. The cost for the unemployment consequences of excessive wage deals in a specific sector can be passed on to tax paying workers in other sectors of the labor market. In the resulting Nash equilibrium real wages will be too high, and aggregate employment too low. This situation can be remedied by changing the financing of unemployment insurance, so that members of sectoral unions have to shoulder a greater part of the marginal cost of unemployment; see Holmlund and Lundborg (1988) for an analysis.

\section{Will the welfare state survive? ${ }^{14}$}

According to the conventional view, increased openness and the requirements imposed by the new economy will increase the costs of preserving institutions that hinder the flexible

\footnotetext{
${ }^{14}$ This section draws on Agell (2002).
} 
adjustment of relative wages. As a consequence governments sooner or later have to liberalise rigid labour market institutions, cut down on generous unemployment insurance, and implement measures that restrict the influence of rent seeking unions. But considerations of political economy suggest that this process is not automatic.

Figure 2 shows the marginal costs and benefits of income redistribution, as perceived by the decisive voter. Since the excess burden increases with the square of the tax wedge the marginal cost curve slopes upwards. Under the plausible assumption that a dollar's worth of income redistribution matters most at a low overall level of income redistribution, the marginal benefit curve slopes downwards. In the initial political economy equilibrium, the decisive voter chooses the amount of redistribution so that the marginal cost and benefit curves intersect, i.e. point $A$. The popular view assumes that globalisation increases the efficiency costs associated with a given level of income redistribution; i.e. the marginal cost curve shifts upwards. We then end up in the political economy equilibrium at point $B$, where the new cost curve intersects the old benefit curve. Clearly, there will be less income redistribution. But to the extent that globalisation also increases the decisive voter's demand for social insurance, there will in fact be a simultaneous upward shift in the benefit curve. We then end up at point $C$, where the new cost curve intersects the new benefit curve. Whether this final political equilibrium is associated with less or more income redistribution is an open question, on which it is hard to form a definite a priori opinion.

The cross-country evidence on the determinants of labour market institutions suggests that the analysis of Figure 2 may have some validity. Researchers have long suggested that the vulnerability of the open economy provides incentives to increase the scope of government. Cameron (1978) showed that the trade to GDP ratio in 1960 was a good predictor of the future growth of tax revenue in a sample of 18 OECD. He also found a positive correlation between openness and a measure of the scope of collective bargaining. 
More recently, Rodrik (1998) has found evidence of a robust positive correlation between openness and indicators of the size of government in a much larger sample. The explanation offered by Rodrik is that government spending plays a risk-reducing role in economies exposed to a significant amount of external risk. In Agell $(1999,2002)$ I show that more open economies on average tend to have higher union density, more centralised wage setting, more compressed wage structures, higher minimum wages, etc.

Where does this leave us? In the words of Krueger (2000, p. 132) “...when the dust settles I suspect that the competing forces of integration and demand for social protection will roughly balance out, and that the broad outlines of today's labour compact in European nations will still be recognisable in the future". In my view, this is as good a guess as any. 


\section{References}

Aaberge, R., Björklund, A., Jäntti, M., Palme, M., Pedersen, P., Smith, N. and Wennemo, T. (2002), "Income inequality and income mobility in the Scandinavian countries compared to the United States". Review of Income and Wealth 48, 443-469.

Acemoglu, D. and Pischke, S. (1999), "The structure of wages and investment in general training". Journal of Political Economy 107, 539-72.

Acemoglu, D. and Shimer, R. (1999), “Efficient unemployment insurance”. Journal of Political Economy 107, 893-928.

Agell, J. (1999), “On the benefits from rigid labour markets: norms, market failures, and social insurance". The Economic Journal 109, F143-F164.

Agell, J. (2002), “On the determinants of labour market institutions: rent-seeking vs. social insurance". German Economic Review 3, 107-135.

Agell, J. and Lommerud, K. E. (1992), “Union egalitarianism as income insurance”. Economica 59, 295-310.

Agell, J. and Lommerud, K. E. (1997), "Minimum wages and the incentives for skill formation". Journal of Public Economics 64, 25-40.

Atkinson, A. B. (1991), "Social insurance”. Geneva Papers on Risk and Insurance Theory 16, 113-131.

Atkinson, A. B. (1999), The economic consequences of rolling back the welfare state. MIT Press, Cambridge.

Atkinson, A. B., Rainwater, L. and Smeeding, T. M. (1995), Income distribution in European countries: evidence from the Luxembourg Income Study. OECD, Paris.

Barr, N. (1998), The economics of the welfare state (third edition). Oxford University Press, Oxford. 
Bertola, G., Blau, F. and Kahn, L. (2001), ”Comparative analysis of labor market outcomes: Lessons for the US from international long-run evidence”. NBER Working Paper No. 8526.

Björklund, A. (1998), "Income distribution in Sweden: what is the achievement of the welfare state?". Swedish Economic Policy Review 5, 39-80.

Björklund, A. and Jäntti, M. (1997), "Intergenerational income mobility in Sweden Compared to the United States". The American Economic Review 87, 1009-1018.

Blank, R. M. (2002). "Evaluating welfare reforms in the United States". Journal of Economic Literature 40, 1105-1166

Blank, R. M. (2003), “U.S. welfare reform: what's relevant for Europe?”. CESifo Economic Studies 49, 49-74.

Blanchard, O. and Wolfers, J. (2000), "The role of shocks and institutions in the rise of European Unemployment: The aggregate evidence”. The Economic Journal 110, C1C33.

Bradbury, B. and Jäntti, M. (2002), “Child poverty across industrialized countries”. Mimeo, Statistics Finland.

Burkhauser, R. and Poupore, J. G. (1997), “A cross-national comparison of permanent inequality in the United States and Germany". Review of Economics and Statistics 79, $10-17$.

Cahuc, P. and Michel, P. (1996), "Minimum wage, unemployment and growth". European Economic Review 40, 1463-1482.

Carneiro, P. and Heckman, J. (2003), "Human capital policy”. NBER Working Paper No. 9425.

Cassel, G. (1900), "En socialpolitik på avvägar” (Social policy on the wrong track). Ekonomisk Tidskrift 2, 385-416. 
Duncan, G., Gustafsson, B., Hauser, R., Schmauss, G. and Messinger, H. (1993), ’Poverty dynamics in eight countries". Journal of Population Economics 6, 215-234.

Dur, R. and Teulings C. (2002), "Education, income distribution and public policy". Mimeo, presented at the CESifo/ISPE workshop on Labour market institutions and public regulation, Cadenabbia 2002.

Fehr, E. and Gächter, S. (2002), ”Altruistic punishment in humans". Nature 415, 137-140.

Gottschalk, P. and Smeeding, T. M. (1997), "Cross-national comparisons of earnings and income inequality". Journal of Economic Literature 35, 633-687.

Heady, C. (1993), “Optimal taxation as a guide to tax policy: a survey”. Fiscal Studies 14, 1541.

Heckman, J. (2001), "Flexibility and job creation: lessons from abroad". Chancen für Alle, Initiative Neue Soziale Marktwirtschaft, Berlin.

Hicks, J. (1946), Value and capital, second edition. Oxford University Press, Oxford.

Holmlund, B. and Lundborg, P. (1988), "Unemployment insurance and union wage setting". Scandinavian Journal of Economics 90, 161-172.

Kahn, L. (2000), “Wage inequality, collective bargaining, and relative employment from 1985 to 1984: Evidence from fifteen OECD countries". The Review of Economics and Statistics 82, 564-579.

Krueger, A. B. (2000), ”From Bismarck to Maastricht: The march to European Union and the labor compact". Labour Economics 7, 117-134.

Krueger, A. (2002), "Inequality, too much of a good thing”. Mimeo, Princeton University.

Lalive, R., van Ours, J. and Zweimuller, J. (2002), “The effect of benefit sanctions on the duration of unemployment”. IZA Discussion Paper No. 469.

Meyer, B. and Rosenbaum, D. T. (2001), "Welfare, the earned-income tax credit, and the labor supply of single mothers". Quarterly Journal of Economics 116, 1063-1114. 
Mirrlees, J. A. (1971), “An exploration in the theory of optimum income taxation”. Review of Economic Studies 38, 175-208.

Nickell, S. (1997), “Unemployment and labor market rigidities: Europe versus North America”. Journal of Economic Perspectives 11, 55-74.

Nickell, S. and Bell, B. (1996), "Changes in the distribution of wages and unemployment in OECD countries". American Economic Review 86 (Papers and Proceedings), 302-308.

Nickell, S. and Layard, R. (1999), "Labour market institutions and economic performance". In Handbook of Labour Economics, volume 3C, North-Holland, Amsterdam.

Pissarides, C. A. (2001), “Employment protection”. Labour Economics 8, 131-159.

Ravn, M and Sørensen, J. R. (1997), “Minimum wages: curse or blessing?”. Research in Labor Economics 16, 343-368.

Rodrik, D. (1998), “Why do more open economies have bigger governments?”. Journal of Political Economy 106, 997-1032.

Sandmo, A. (1991), "Economists and the welfare state”. European Economic Review 35, 213239.

Sandmo, A. (1998), “The welfare state: a theoretical framework for justification and criticism”. Swedish Economic Policy Review 5, 11-33.

Sinn, H.-W. (1995), "A theory of the welfare state". Scandinavian Journal of Economics 97, $495-526$.

Sinn, H.-W. (1996), "Social insurance, incentives and risk taking”. International Tax and Public Finance 3, 259-280.

Smeeding, T. (2002), "Globalization, inequality and the rich countries of the G-20: evidence from the Luxembourg income study (LIS)”, Luxembourg Income Study Working paper No. 320 . 
Solon, G. (2002), "Cross-country differences in intergenerational earnings mobility". Journal of Economic Perspectives 16, 59-66.

Summers, L. (1993). "Taxation and the structure of labour markets: the case of corporatism". Quarterly Journal of Economics 108, 385-411. 
Table 1. Inequality indices according to the Luxembourg Income Study (mid to late 1990s)

\begin{tabular}{|c|c|c|c|c|c|}
\hline & $\begin{array}{l}90 / 10 \text { decile } \\
\text { ratio }\end{array}$ & Gini-coefficient & $\begin{array}{l}\text { Percentage of } \\
\text { population in } \\
\text { relative poverty }\end{array}$ & $\begin{array}{l}\text { Percentage of } \\
\text { children in } \\
\text { relative poverty }\end{array}$ & $\begin{array}{c}\text { Percentage of } \\
\text { children in } \\
\text { absolute poverty }\end{array}$ \\
\hline & & & Scandinavia & & \\
\hline Sweden & 2.61 & .221 & 6.6 & 2.6 & 5.3 \\
\hline Finland & 2.68 & .226 & 5.4 & 2.8 & 6.9 \\
\hline Denmark & 2.83 & .257 & 9.2 & 8.7 & 5.1 \\
\hline \multirow[t]{2}{*}{ Norway } & 3.15 & .238 & 6.9 & 3.9 & 3.0 \\
\hline & \multicolumn{5}{|c|}{ Northern and Continental Europe } \\
\hline Luxembourg & 2.92 & .235 & 3.9 & 4.5 & 1.2 \\
\hline Netherlands & 3.15 & .253 & 8.1 & 8.1 & 11.1 \\
\hline Germany & 3.18 & .261 & 7.5 & 10.6 & 12.5 \\
\hline Belgium & 3.26 & .255 & 8.0 & 7.7 & 7.5 \\
\hline France & 3.54 & .288 & 8.0 & 7.9 & 10.7 \\
\hline Switzerland & 3.62 & .307 & 9.3 & 10.0 & -- \\
\hline \multirow[t]{2}{*}{ Austria } & 3.73 & .277 & 10.6 & 15.0 & -- \\
\hline & \multicolumn{5}{|c|}{ Southern Europe } \\
\hline Spain & 3.96 & .303 & 10.1 & 12.2 & 42.8 \\
\hline \multirow[t]{2}{*}{ Italy } & 4.77 & .342 & 14.2 & 20.2 & 36.1 \\
\hline & \multicolumn{5}{|c|}{ English-speaking countries } \\
\hline Canada & 4.13 & .305 & 12.8 & 16.3 & 9.5 \\
\hline Australia & 4.33 & .311 & 14.3 & 15.8 & 16.2 \\
\hline Ireland & 4.33 & .325 & 12.3 & 14.4 & 21.4 \\
\hline United Kingdom & 4.57 & .344 & 12.5 & 15.4 & 29.1 \\
\hline United States & 5.57 & .372 & 17.0 & 21.9 & 13.9 \\
\hline
\end{tabular}

Sources: Numbers in columns 1-4 are from Smeeding (2002) and www.lisproject.org/keyfigures. Those in column 5 are from Bradbury and Jäntti (2002). Relative poverty is the percentage of individuals with a disposable income below 50 percent of the median disposable income. Absolute poverty is the percentage of children with real incomes below the official US poverty line. The square root of the number of household members is used as the

equivalence scale. For most countries the data refer to the late 1990s. The numbers for Germany includes both the former East and West Germany. 
Figure 1. Relative child poverty versus social expenditure as a percentage of GDP in 18 OECD countries




Figure 2. Effect of globalisation on redistribution in political economy equilibrium

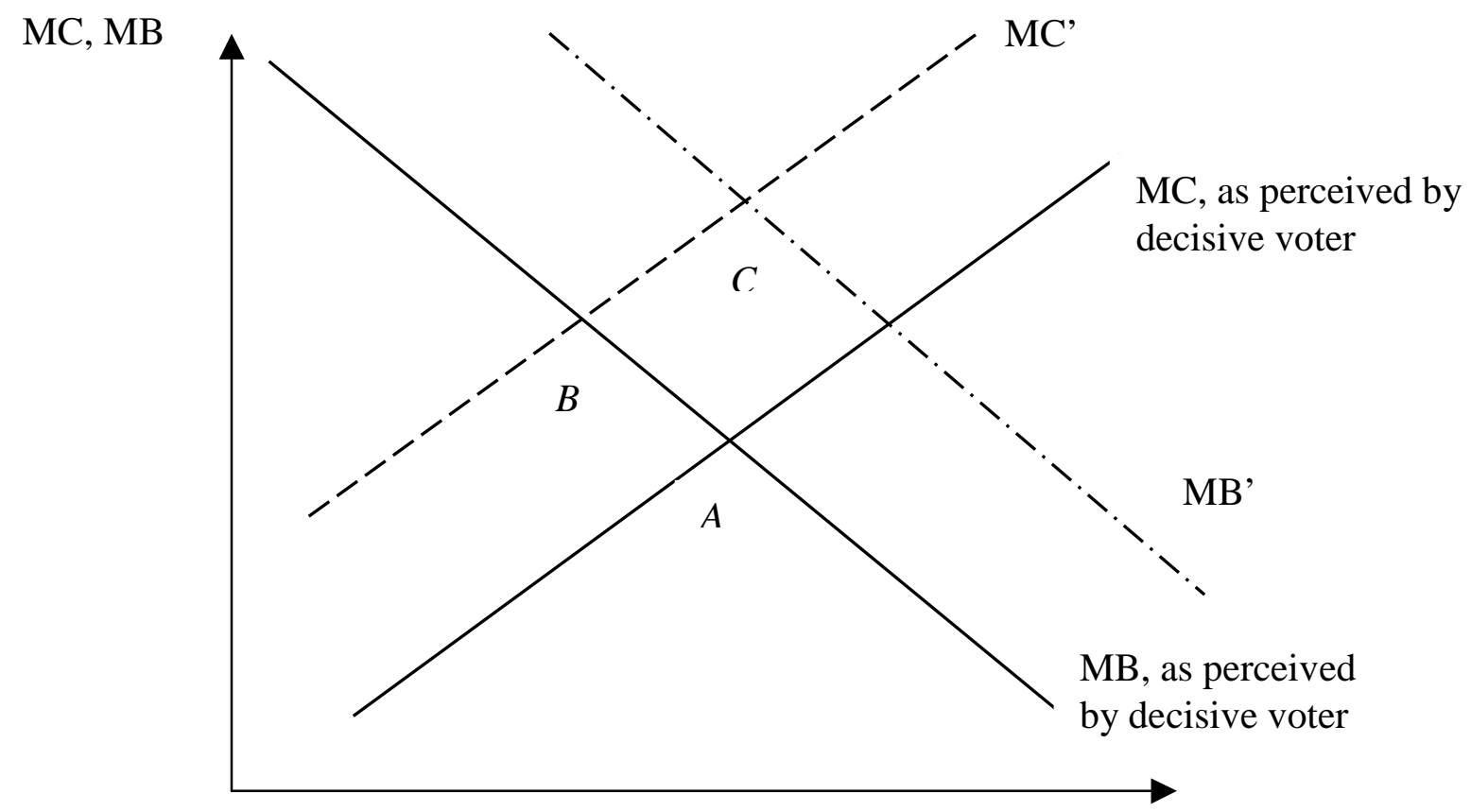

Size of redistributive budget 